\title{
Radiological evaluation of acromial characteristic using supraspinatus outlet view in shoulder impingement syndrome
}

\author{
Marcel Prasetyo $^{1}$, N.Diana Yulisa ${ }^{1}$, Elida Ilyas ${ }^{2}$, Joedo Prihartono ${ }^{3}$
}

\begin{abstract}
Abstrak
Tujuan penelitian ini ialah mengetahui hubungan antara shoulder impingement syndrome (SIS) dengan karakteristik morfologi akromion (sudut acromial tilt akromion, osteofit subakromion). Pemeriksaan radiografi konvensional proyeksi supraspinatus outlet dilakukan dengan bantuan fluoroskopi terhadap 40 penderita SIS dan 40 individu tanpa nyeri bahu sebagai pembanding, dilanjutkan dengan pengukuran sudut acromial tilt, penentuan tipe akromion (menurut klasifikasi Bigliani dan kriteria Park) serta ada/tidaknya osteofit subakromion. Kelompok penderita SIS memiliki rerata sudut acromial tilt $\left.34,1^{\circ}(S D) 7,6\right)$ sementara kelompok tanpa nyeri bahu memiliki rerata sudut $32,1^{\circ}$ (SD 7,7). Tidak ditemukan hubungan yang bermakna secara statistik $(p=0,241)$ antara sudut acromial tilt dengan SIS. Mayoritas tipe akromion adalah tipe II (lengkung) pada kedua kelompok (85\% dan 95\%), tidak ditemukan hubungan bermakna secara statistik $(p=0,224)$ antara tipe akromion dengan SIS. Sebesar 52,5\% penderita SIS ditemukan memiliki osteofit subakromion dibandingkan dengan 12,5\% pada kelompok pembanding, dan terdapat hubungan bermakna secara statistik $(p=$ 0,0003) antara osteofit subakromion dengan SIS. Osteofit subakromion memiliki hubungan bermakna dengan timbulnya SIS, sementara tipe akromion dan sudut acromial tilt tidak berhubungan dengan SIS. (Med J Indones 2007; 16:176-80)
\end{abstract}

\begin{abstract}
Purpose of this study was to find the association between shoulder impingement syndrome (SIS) and morphological characteristics of acromion (acromial tilt angle, type of acromion, subacromial osteophyte). Supraspinatus outlet view was performed using fluoroscopy. There were 40 SIS patients and 40 individuals with no shoulder pain examined and measured for their acromial tilt angle, type of acromion (according to Bigliani's classification and Park's criteria) and for the presence of subacromial osteophyte. Average acromial tilt angle was $34.1^{\circ}$ (SD 7.6) for SIS group and 32.1 (SD 7.7) for control group. Type II acromion was found more frequent in both groups (85\% and 95\%). The association between SIS and acromial tilt angle or between SIS and type of acromion were statistically insignificant $(p=0.241$ and $p=0.221)$. Subacromial osteophyte was found in $52.5 \%$ of SIS group compare to $12.5 \%$ among the control group, and the association with SIS was statistically significant $(p=0.0003)$. Subacromial osteophyte was found to have significant association with SIS. Such association was not found in acromial tilt angle and type of acromion. (Med J Indones 2007; 16:176-80)
\end{abstract}

Keywords : shoulder impingement syndrome, acromion, supraspinatus

Shoulder impingement syndrome is (SIS) impingement of muscle and bursae in subacromial space due to narrowing of the space (i.e. space between acromion, coracoacromial arch and humeral head). ${ }^{1-3}$ The incidence is approximately $70 \%$ of shoulder disease. ${ }^{4}$ Incidence is higher in workers, related to biomechanical risk factors such as tools or overhead activities. This

\footnotetext{
${ }^{1}$ Department of Radiology, Faculty of Medicine University of Indonesia/Dr. Cipto Mangunkusumo Hospital, Jakarta, Indonesia

2 Department of Medical Rehabilitation, Dr. Cipto Mangunkusumo Hospital, Jakarta, Indonesia

${ }^{3}$ Department of Community Medicine, Faculty of Medicine, University of Indonesia, Jakarta, Indonesia
}

condition may cause significant functional disability and decreased quality of life. ${ }^{3,5}$

The concept of impingement was introduced in 1972 by Neer, and since then many studies have been conducted to analyze role of acromial morphology in impingement syndrome. Some studies have found that type III of acromion and subacromial osteophytes are associated to impingement syndrome and rotator cuff tears. $^{3,6-8}$ Prato et $\mathrm{al}^{9}$ have conducted a study on acromial tilt angle and found significant difference of angle between normal individual $36.20^{\circ}$ (SD 1.00) and individual with chronic impingement $30.00^{\circ} \mathrm{SD}$ 0.70). However, Hyvönen et $\mathrm{al}^{6}$ have found no correlation between acromial morphology (acromial tilt angle, acromial type) and impingement syndrome. 
Conventional radiography is an important diagnostic tool in the management of SIS, regarding the major role of extrinsic compression of supraspinatus tendon in the pathogenesis of this syndrome. ${ }^{7,10-12}$ Supraspinatus outlet view (SOV) using fluoroscopy can visualize acromial morphology and subacromial osteophytes superiorly. ${ }^{7,9}$

\section{METHODS}

This comparative cross-sectional study was conducted at the Department of Radiology, Cipto Mangunkusumo Hospital between March-May 2006. There were 80 subjects, categorized in two groups of 40 subjects with SIS and 40 subjects with no shoulder pain. Criteria for SIS group were patients, age >25 years with history and physical examination consistent with SIS, positive Hawkins-Kennedy test with degree of pain $\geq 5$ according to visual analogue scale (VAS), and have agreed to participate. Additional criteria for the control group was $\geq 25$ years subjects with VAS $=0$ in any shoulder movement. Subjects with history of bone fracture in the shoulder area, pregnancy, degenerative arthritis of the shoulder, and cervical radiculopathy were excluded. Hawkins-Kennedy test is performed by positioning the arm in flexion position with passive $90^{\circ}$ anterior elevation, then any shoulder pain generated by passive internal rotation of the gives positive result. ${ }^{1,13}$ Degree of pain was measured using visual analogue scale, in which subject marked one point of a line scaled from 0 (no pain) to 10 (severe pain), according to the severity of pain. $^{14}$

The radiograph of supraspinatus outlet view was produced using radiography-fluoroscopy instrument Philips EasyDiagnost, postero-anterior X-ray beam at $70 \mathrm{kVp}$ and $12 \mathrm{mAs}$ tailored to body habitus, with central beam at humeral head. Participant was standing in oblique $45^{\circ}$, and under fluoroscopic guidance the scapula was positioned to make the axis of scapula inline with the axis of humerus. Due to limitation of the instruments, subject need to bend contralaterally to obtain an optimal view of subacromial space. The projection was considered optimal if the center point of Y-configuration of the scapula was located in the center of humeral head, and no double contour should be seen. Acromial type was determined based on criteria by Park $^{8}$ (figure 1), and acromial tilt angle was measured based on the reference lines of Prato ${ }^{9}$ (figure 2). All datas were collected, including sex, age, and morphological characteristic of acromion (acromial tilt angle, acromial type, and presence of subacromial osteophytes). Statistical analysis was performed using Chi Square test, Student-t test, and Kolmogorov-Smirnov test.

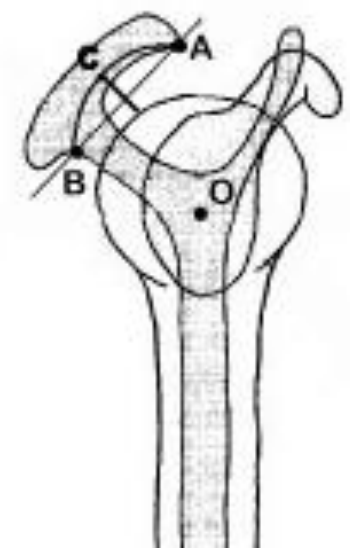

Figure 1. Types of acromion according to Bigliani and Park's criteria ${ }^{8}$

Point $\mathrm{O}$ : center of humeral head.

Point A : inferior rim of anterior part of acromion.

Point B : inferior rim of posterior part of acromion.

Point $\mathrm{C}$ : point of acromial arch intersected with a line perpendicular to the midpoint of $\mathrm{AB}$ line.

Type 1 : point $\mathrm{C}$ located on $\mathrm{AB}$ line.

Type $2: \mathrm{OA}=\mathrm{OC}$, or $\mathrm{OA}>\mathrm{OC}$.

Type $3: \mathrm{OA}<\mathrm{OC}$

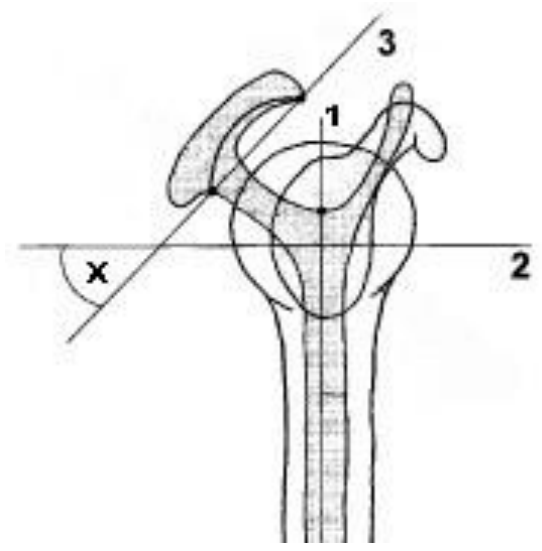

Figure 2. Reference lines for acromial tilt angle measurement ${ }^{9}$

Line 1 = axis of scapula, superimposed with axis of humerus.

Line 2 = horizontal line perpendicular to line 1 .

Line 3 = line passing through lowest points of acromial arch.

$\mathrm{X}=$ acromial tilt angle 


\section{RESULTS}

Proportion of female was higher than male in both groups (65\% vs 35\% in SIS group, and 55\% vs $45 \%$ in control group). Total number of females in SIS group was higher than in control group.

Table 1. Proportion of subjects according to study groups

\begin{tabular}{lccc}
\hline & \multicolumn{2}{c}{ Study groups } & \\
\cline { 2 - 3 } & SIS & $\begin{array}{c}\text { No shoulder } \\
\text { pain }\end{array}$ & \\
\hline Sex & & & \\
Male & $14(35 \%)$ & $18(45 \%)$ & 0.494 \\
Female & $26(65 \%)$ & $22(55 \%)$ & \\
\hline $\begin{array}{l}\text { Age group } \\
<40 \text { years }\end{array}$ & $14(35 \%)$ & $25(62,5 \%)$ & 0.025 \\
$\geq 40$ years & $26(65 \%)$ & $15(37,5 \%)$ & \\
\hline
\end{tabular}

Most subjects had type II acromion. KolmogorovSmirnov test showed no significant difference ( $\mathrm{p}$ value 0.224 ) between the two groups.

Table 2. Morphological type of acromion according to study group

\begin{tabular}{lccc}
\hline \multirow{2}{*}{$\begin{array}{c}\text { Type of } \\
\text { acromion }\end{array}$} & $\begin{array}{c}\text { SIS } \\
(\mathrm{n}=40)\end{array}$ & $\begin{array}{c}\mathrm{p} \\
\text { No shoulder } \\
\text { pain }(\mathrm{n}=40)\end{array}$ & \\
\cline { 2 - 3 } value \\
Type of acromion & & & \\
I & $3(7.5 \%)$ & $1(2.5 \%)$ & 0.224 \\
II & $34(85 \%)$ & $38(95 \%)$ & \\
III & $3(7.5 \%)$ & $1(2.5 \%)$ & \\
\hline Osteophytes & & & \\
Yes & $21(52.5 \%)$ & $5(12.5 \%)$ & 0.0003 \\
No & $19(47.5 \%)$ & $35(87.5 \%)$ & \\
\hline $\begin{array}{l}\text { Mean of } \\
\text { acromial tilt } \\
\text { angle }\end{array}$ & $34.1^{\circ}(\mathrm{SD} 7.6)$ & $32.1^{\circ}(\mathrm{SD} 7.7)$ & 0.241 \\
\hline
\end{tabular}

Mean of acromial tilt angle was $34.1^{\circ}$ (SD 7.6) for SIS group, while mean in control group was only $32.1^{\circ}$ (SD 7.7). No significant difference was found between the two groups.

Subacromial osteophytes was found in $52.5 \%$ subjects of SIS group, but in control group it was only $12.5 \%$. Chi-square test has found significant difference between both groups ( $\mathrm{p}$ value $=0.0003$ )

Although subacromial osteophytes and age showed significant association, further analysis using logistic regression multivariate test found no association between age of both groups $(p$ value $=0.09$ ). Subacromial osteophytes was found to have significant association $(\mathrm{p}$ value $=0.01)$

Table 3. Logistic regression multivariate analysis of age and subacromial osteophytes

\begin{tabular}{ccccc}
\hline Variable & $\begin{array}{c}\mathrm{p} \\
\text { value }\end{array}$ & $\begin{array}{c}\text { Odds } \\
\text { ratio }\end{array}$ & $\begin{array}{c}\text { OR lower } \\
\text { limit }\end{array}$ & $\begin{array}{c}\text { OR upper } \\
\text { limit }\end{array}$ \\
\hline $\begin{array}{c}\text { Subacromial } \\
\text { osteophytes } \\
\text { Age }\end{array}$ & 0.01 & 6.629 & 2.108 & 20.848 \\
\hline
\end{tabular}

\section{DISCUSSION}

The concept of impingement syndrome introduced by Neer have been studied in many countries, especially in its association with acromial type and acromial tilt angle. According to acromial classification by Bigliani, type III (hooked) is known to be associated with SIS and rotator cuff disease. ${ }^{2,3,8,10}$ However, Prescher ${ }^{16}$ have argued that type III acromion is actually type II (curved) with subacromial osteophytes.

Type II acromion was found in most subjects, consistent with other literatures. Type III acromion was only seen in 4 subjects, but it was always accompanied by subacromial osteophytes. This study did not include osteophytes in determining acromial type using Park's criteria, since osteophytes is an acquired pathological process and not part of the initial shape of acromion. ${ }^{8,9}$ Type III acromion was found although subacromial osteophytes was excluded, indicating that type III is not the same as type II with osteophytes, as defined by Prescher. ${ }^{16}$
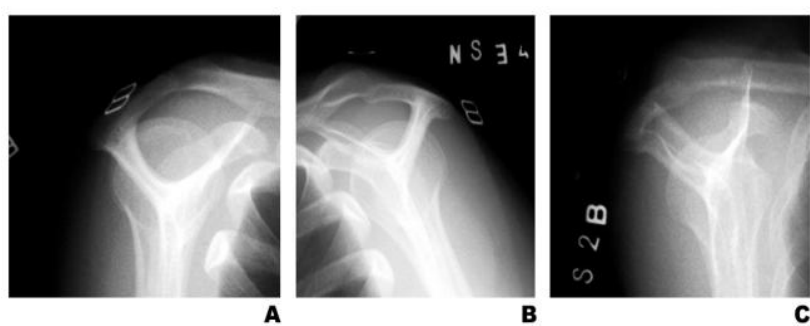

Figure 3. Types of acromion according to Bigliani

A = Type I (flat). B = Type II (curved). C = Type III (hooked).

Statistical analysis of acromial type using KolmogorovSmirnov have found no significant difference ( $\mathrm{p}$ value $=0.224)$. Proportion of the three types was relatively 
the same in both groups. This could mean the presence of additional factors in SIS, consistent with multifactorial aetiology described by Pribicevic and Pollard. ${ }^{3}$

Acromial tilt angle was measured in this study using the same reference lines as in the study by Prato. Subacromial osteophytes was not included. Mean acromial tilt angle is $34.1^{\circ}\left(21^{\circ}-50^{\circ}\right)$ for SIS group and $32.1^{\circ}\left(20^{\circ}-50^{\circ}\right)$ for control group. The narrowest angle was even found in the control group. This finding was contradictive to the study by Prato, who found a narrower angle for SIS group compare to normal individual. Statistical analysis using Chi-Square test also found no significant difference. This result was quite similar to the study by Hyvönen, ${ }^{6}$ who found no significant difference in acromial tilt angle between impingement and control group $\left(30.8^{\circ}\right.$ vs $\left.31^{\circ}\right)$. However, several limitations must be considered. Although Hawkins-Kennedy test is very sensitive and in combination with careful history taking is adequate, it lacks of specificity and the diagnosis of impingement is ideally established using impingement lidocain test. $^{11,13}$ History taking was often unclear, due to unawareness of the subjects since they rarely perform overhead shoulder activity. Another possibility is the presence of other types of impingement, such as coracoacromial ligament hypertrophy and subcoracoid impingement.

However, both groups had mean acromial tilt angles narrower than in comparison to study by Prato $^{9}\left(32.1^{\circ}\right.$ vs $36.2^{\circ}$ in SIS group, $34.1^{\circ}$ vs $36.2^{\circ}$ in control group). Hyvönen ${ }^{6}$ have found even narrower angles $\left(30.8^{\circ}\right.$ in SIS group, $31^{\circ}$ in control group). This could mean that race factor play some role in impingement syndrome, but further study is needed because so far there is no study comparing acromial structure between different races.

Subacromial osteophytes was found in $52.5 \%$ subjects in SIS group, but it was only $12.5 \%$ in control group. A good correlation with impingement was found using either Chi Square test $(p$ value $=0.0003)$ and logistic regression multivariate analysis $(\mathrm{p}$ value $=$ 0.01 ), with Odds ratio 6.629. This could mean that individuals with subacromial osteophytes is 6.6 times more likely to have impingement.

It was also interesting to see the advantage of supraspinatus outlet view in visualizing subacromial osteophytes. Even minimal osteophytes that showed only sclerotic irregular borders could be visualized very nicely, thus supporting the importance of this view as one of the radiographic examination series of impingement syndrome. ${ }^{7,11,15}$ However, optimal result can only be achieved by using fluoroscopy, especially in obtaining optimal caudal tilt of X-ray beam regarding wide variation of acromial anatomy. ${ }^{7,15}$ The difficulty in positioning was not just the caudal tilt of the beam, but also in visualizing true lateral view of the acromion and scapular blade. Many variations have been found in this study, such as short acromion, curved scapular blade, long and thick clavicule, and unsynchronized position of scapular spine to scapular blade. Those variations caused significant problems in positioning the scapula according to the method established by Prato.

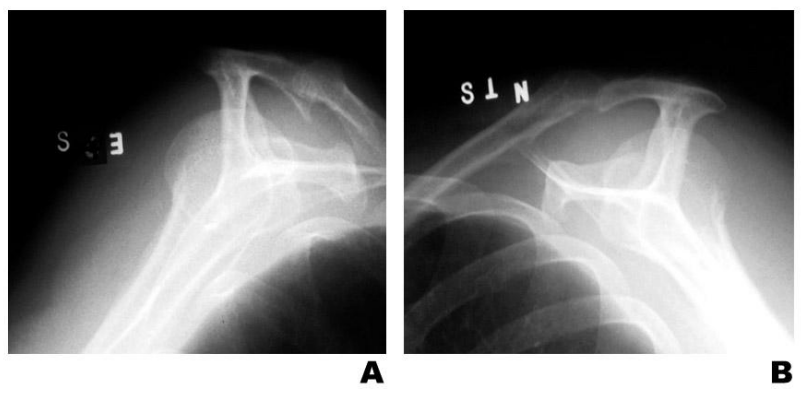

Figure 4. Subacromial osteophyte

(A) There is a prominent osteophytes easily identified by supraspinatus outlet view.

(B) Even a minimal osteophyte can also be visualized.

Females was found more frequent in SIS group, similar to the study by Van der Windt ${ }^{17}$ about the incidence of shoulder pain. Age of the subjects was higher in SIS group compare to control group, but no significant difference was found, probably due to uneven distribution of age between both groups.

There are some limitations found in this study. Supraspinatus outlet view needed precise positioning of the patient, which sometimes could not be obtained because the patient was unable to maintain stable position or because of the variability of scapular shape. Other limitation was the difficulty in finding subjects with comparable age between both groups.

\section{CONCLUSION}

Most frequent type of acromion was type II (curved). No significant correlation was found between acromial type and SIS, or between acromial tilt angle and SIS. Subacromial osteophytes associated to SIS significantly. Individual with subacromial osteophytes was more 
likely to have SIS compare to individual with no subacromial osteophytes.

Further studies are required with large number of subjects and better comparability. Supraspinatus outlet view using fluoroscopy is useful in detecting subacromial osteophytes in cases of shoulder impingement syndrome.

\section{REFERENCES}

1. Koester MC, George MS, Kuhn JE. Shoulder impingement syndrome. Am J Med. 2005;118:452-5.

2. Lewis SJ, Green A, Dekel S. The aetiology of subacromial impingement syndrome. Physiotherapy. 2001;87(9):458-69.

3. Pribicevic M, Pollard H. Rotator cuff impingement. J Manipul Physiol Ther. 2003;27(9):580-9.

4. Chard MD, Hazleman R, Hazleman BL, King RH, Reiss BB. Shoulder disorders in elderly: a community survey. Arthritis Rheum. 1991;34:766-9.

5. Chipchase LS, O'Connor DA, Costi JJ, Krishnan J. Shoulder impingement syndrome : preoperative health status. J Shoulder Elbow Surg. 2000;9:12-5.

6. Hyvönen $\mathrm{P}$, et al. Supraspinatus outlet view in the diagnosis of stages II and III impingement syndrome. Acta Radiologica. 2001;42:441-6.

7. Duralde XA, Gauntt SJ. Troubleshooting the supraspinatus outlet view. J Shoulder Elbow Surg. 1999;8:314-9.

8. Park TD, Park DW, Kim SI, Kweon TH. Roentgenographic assessment of acromial morphology using supraspinatus outlet radiographs. Arthroscopy. 2001;17(5):496-501.
9. Prato N, Peloso D, Franconeri A, Tegaldo G, Ravera GB, Silvestri E, et al. The anterior tilt of the acromion : radiographic evaluation and correlation with shoulder diseases. Eur Radiol. 1998;8:1639-46.

10. Stiles RG, Otte MT. Imaging of the shoulder. Radiology. 1993;188:603-13.

11. Chang WK. Shoulder impingement syndrome. [Online]. 2005 Jul 22 [cited 2006 Jan 15]; Available from: URL: http://www.emedicine.com/SPORTS/topic119.htm

12. Greenspan A. Upper limb : shoulder girdle. In : Greenspan A, editor. Orthopaedic radiology. 5th ed. New York : Lippincott; 2005. p.94-108.

13. Calis M, Akgun K, Birtane M, Karacan I, Calis H, Tuzun F. Diagnostic values of clinical diagnostic tests in subacromial impingement syndrome. Ann Rheum Dis. 2000;59:44-7.

14. Garrison SJ. Handbook of physical medicine and rehabilitation basics. Philadelphia : JB Lippincott Co.; 1995.

15. Newhouse KE, El-Khoury GY, Nepola JV, Montgomery WJ. The shoulder impingement view: a fluoroscopic technique for the detection of subacromial spurs. Am J Roentgenol. 1988;151:539-41.

16. Prescher A. Anatomical basics, variations, and degenerative changes of the shoulder joint and shoulder girdle. Eur $\mathbf{J}$ Radiol. 2000;35:88-102.

17. Van der Windt, Koes BW, de Jong BA, Bouter LM. Shoulder disorders in general practice : incidence, patient characteristics, and management. Ann Rheum Dis. 1995; 54:959-64. 